\title{
What I did over my summer vacation
} LibGuides Summer Project

M ost instructional librarians have a body of LibGuides that they must keep up-to-date as part of their duties of the job, but the truth is that many librarians do not have time to make this essential duty a top priority. A cursory glance over a single guide may be given when a professor brings students in for an information literacy session, but a holistic and in-depth cleanup of content and the application of new tips and tricks are not usually at the top of the to-do list.

The instructional design librarian at East Carolina University's Joyner Library has attempted to address issues with out-of-date content in LibGuides by conducting an annual group cleanup project during the lull in classroom instruction occurring over the summer. Called the LibGuides Summer Project, the team of instructional librarians is provided with a brief weekly instruction session on a feature of LibGuides or a best practice in web design. Librarians are then given one week to make this change to their own guides. ${ }^{1}$

\section{Is it hot enough for you?}

The LibGuides Summer Project has taken place at Joyner Library over the last three summers and has resulted in fewer broken links, improved content, as well as a more unified look and feel.

At the beginning of the summer, a lesson plan for the entire summer project is provided by the project leader to the participants. The lesson plan uses the instructional concept of scaffolding, resulting in weekly sessions that build upon themselves and become more complex as the project progresses. During weekly departmental meetings, the project leader presents that week's 15-minute lesson, including handson instruction in a library classroom.

The librarians are given one week to apply that week's lesson to their own guides. A weekly "LibGuides Office Hour" offering optional one-on-one guided help is provided by the project leader a few days later for those having trouble applying new concepts. The LibGuides Summer Project can last as few as six weeks or stretch to fill up the summer with twelve lessons.

Examples of clean-up lessons for the LibGuides Summer Project include checking for broken links, reviewing statistics and deciding whether to keep certain LibGuides or set them to private, and fixing old catalog and chat boxes if there were recent changes to the systems or website. Subsequent lessons can focus on reducing text and increasing interactivity by increasing the amount of tutorial videos, quizzes,

Katy Kavanagh Webb is head of research and instructional services at East Carolina University's J.Y. Joyner Library, email: kavanaghk@ecu.edu

(c) 2015 Katy Kavanagh Webb 
and instructional activities. Near the end of the project, lessons can set librarians to work on adding accessibility features to the guides for individuals with disabilities. In summer 2014, the LibGuides Summer Project was used to make the change to LibGuides 2.0 and featured lessons on new functionality in the updated platform. Furthermore, due to the changes occurring across the board to the LibGuides platform, the project was expanded to include additional departments, including the Health Sciences library on campus, instead of simply focusing on instructional librarians at the main branch.

\section{Take the leap}

Some tips if you would like to do this at your library:

- Prepare. The preparation stage will require some research and work on the part of the project leader. Get your template made or get it up to date. If you are the project leader, get your LibGuides updated first to model examples of best practices. If there are boxes that require a bit of tricky technological footwork, such as special boxes linking to the catalog or those using API, set these up for participants so that they can simply borrow the boxes from the template guide. Create an organized lesson plan that involves manageable changes that can be completed in a week's time.

- Pad the time. It is the summer, after all. When creating the lesson plan, look at the calendar. Family trips, holidays like the Fourth of July, and annual conferences mean that there will be multiple absences. Set yourself up for success by planning to skip a lesson during those weeks. Padding the time with a few breaks will ensure that project participants do not fall behind, and it will give those who have fallen behind the chance to catch up. Allow two weeks to complete more complex tasks, if necessary.

- Peer review. Consider having participants in the project look at others' work. Peer review and spot-checking of the assigned updates may occur throughout the project, or build it in to the end of the project as the last assignment. The project leader can also offer individual content review sessions during the weekly office hour.

The LibGuides Summer Project ensures that content is systematically checked and refreshed at least one time during the year. Applying instructional practices common in college classrooms, such as scaffolding, lesson planning, modeling, office hours, and peer review sets your librarians up for success. By breaking the work up into bitesized pieces and making it a priority project to be completed as a group, participating librarians will actually update their content and include updated and novel material on their guides.

\section{Notes}

1. To see examples of two years of LibGuides Summer Project lesson plans to use as a template, please visit: http:// media.lib.ecu.edu/LibGuides/SummerProject.docx. $\boldsymbol{n}$

\section{ACRL-Choice webinars}

The ACRL-Choice webinar program connects academic and research librarians with content and service providers, publishers, and other experts. Upcoming topics include:

Key Trends in Social Science Research (May 12, 2015)

Giving Sisyphus a Push:Promoting discovery at every stage of the eBooks lifecycle (May 14 2015)

Additional information on the program, along with registration links and an archive of past webinar recordings, is available on the Choice website at www.choice 360. org/acrl-choice-webinars/ events. 